\title{
The NASA Lightning Nitrogen Oxides Model (LNOM): Application to Air Quality Modeling
}

\author{
William Koshak ${ }^{1}$, Harold Peterson ${ }^{2}$, Maudood Khan ${ }^{3}$, Arastoo Biazar ${ }^{4}$, Lihua Wang ${ }^{5}$
}

1. NASA Marshall Space Flight Center, VP61, Huntsville, AL, 35805, USA, william.koshak@nasa.gov

2. National Space Science \& Technology Center, NPP, Huntsville, AL 35805, USA, harold.peterson@nasa.gov

3. Universities Space Research Association, Huntsville, AL 35805, USA, maudood.n.khan@nasa.gov

4. University of Alabama in Huntsville, Huntsville, AL 35805, USA, arastoo.biazar@nsstc.uah.edu

5. University of Alabama in Huntsville, Huntsville, AL 35805, USA, lihuawang@nsstc.uah.edu

\begin{abstract}
Recent improvements to the NASA Marshall Space Flight Center Lightning Nitrogen Oxides Model (LNOM) and its application to the Community Multiscale Air Quality (CMAQ) modeling system are discussed. The LNOM analyzes Lightning Mapping Array (LMA) and National Lightning Detection Network $^{\mathrm{TM}}$ (NLDN) data to estimate the raw (i.e., unmixed and otherwise environmentally unmodified) vertical profile of lightning $\mathrm{NOx}\left(=\mathrm{NO}+\mathrm{NO}_{2}\right)$. The latest LNOM estimates of lightning channel length distributions, lightning 1-m segment altitude distributions, and the vertical profile of lightning NOx are presented. The primary improvement to the LNOM is the inclusion of non-return stroke lightning NOx production due to: (1) hot core stepped and dart leaders, (2) stepped leader corona sheath, K-changes, continuing currents, and M-components. The impact of including LNOM-estimates of lightning NOx for an August 2006 run of CMAQ is discussed.
\end{abstract}

* Correspondence to:

William Koshak, Earth Science Office (VP61), NASA Marshall Space Flight Center, 320 Sparkman Drive, Huntsville, AL 35805, USA, Email: william.koshak@nasa.gov 


\title{
The NASA Lightning Nitrogen Oxides Model (LNOM): Application to Air Quality Modeling
}

\author{
William Koshak ${ }^{1}$, Harold Peterson ${ }^{2}$, Maudood Khan ${ }^{3}$, Arastoo Biazar ${ }^{4}$, Lihua Wang ${ }^{5}$
}

1. NASA Marshall Space Flight Center, VP61, Huntsville, AL, 35805, USA, william.koshak@ nasa.gov

2. National Space Science \& Technology Center, NPP, Huntsville, AL 35805, USA, harold.peterson@ nasa.gov

3. Universities Space Research Association, Huntsville, AL 35805, USA, maudood.n.khan@nasa.gov

4. University of Alabama in Huntsville, Huntsville, AL 35805, USA, arastoo.biazar@nsstc.uah.edu

5. University of Alabama in Huntsville, Huntsville, AL 35805, USA, lihuawang @ nsstc.uah.edu

\begin{abstract}
Recent improvements to the NASA Marshall Space Flight Center Lightning Nitrogen Oxides Model (LNOM) and its application to the Community Multiscale Air Quality (CMAQ) modeling system are discussed. The LNOM analyzes Lightning Mapping Array (LMA) and National Lightning Detection Network ${ }^{\text {TM }}$ (NLDN) data to estimate the raw (i.e., unmixed and otherwise environmentally unmodified) vertical profile of lightning $\mathrm{NOx}\left(=\mathrm{NO}+\mathrm{NO}_{2}\right)$. The latest LNOM estimates of lightning channel length distributions, lightning 10-m segment altitude distributions, and the vertical profile of lightning NOx are presented. The primary improvement to the LNOM is the inclusion of non-return stroke lightning NOx production due to: hot core stepped and dart leaders, stepped leader corona sheath, K-changes, continuing currents, and M-components. The impact of including LNOM-estimates of lightning NOx for an August 2006 run of CMAQ is discussed. Global estimates of lightning NOx are also provided using the NASA satellite global lightning climatology.
\end{abstract}

\section{INTRODUCTION}

The methodologies for estimating lightning NOx have involved theoretical and laboratory studies, studies that attempt to combine aircraft measurements with modeling results, and studies that are based on satellite observations. Unfortunately, there has been considerable variability in the estimates of lightning NOx production per flash; see for example the summary table in Labrador et al. (2004) and the review paper by Schumann and Huntrieser (2007). The variability in these estimates is linked to the differences in the measurements and estimation methods employed, and the natural variability of lightning. Recently, the NASA Marshall Space Flight Center introduced the Lightning Nitrogen Oxides Model (LNOM; Koshak et al., 2010) to combine routine and accurate measurements of lightning with Wang et al. (1998) lightning NOx laboratory results.

In the present study, we implement important upgrades to the LNOM, and apply it to analyze thunderstorms occurring over North Alabama for the following months: August 2005, August 2006, August 2007, August 2008, and August 2009. The LNOM-derived lightning NOx profiles are then used to assess the impact of lightning NOx on an August 2006 run of the Community Multiscale Air Quality (CMAQ) modeling system. Global estimates of lightning NOx production are also provided using the NASA Optical Transient Detector (OTD) and Lightning Imaging Sensor (LIS) global lightning climatology.

* Correspondence to:

William Koshak, Earth Science Office (VP61), NASA Marshall Space Flight Center, 320 Sparkman Drive, Huntsville, AL 35805, USA, Email: william.koshak@nasa.gov 


\section{THE LNOM}

\subsection{Basic Functionality}

The LNOM ingests lightning VHF source location (and time-of-occurrence) data such as obtained from the North Alabama Lightning Mapping Array (NALMA). It also ingests location, time-of-occurrence, peak current, and stroke multiplicity data from the National Lightning Detection Network ${ }^{\mathrm{TM}}$ (NLDN). These data are used to determine the flash type (ground or cloud) of each flash occurring within an analysis cylinder (height 0-20km, and radius $20.31 \mathrm{~km}$ ). This cylinder is the approximate volume equivalent of a $36 \mathrm{~km}$ x $36 \mathrm{~km}$ CMAQ grid cell. The LNOM analyzes the VHF sources to estimate the total channel length of each flash. It also chops each portion of a flash contained in the analysis cylinder into 10-m segments to determine the Segment Altitude Distribution (SAD) within the cylinder. Finally, it computes the vertical lightning NOx profile in the cylinder; see Figure 1.
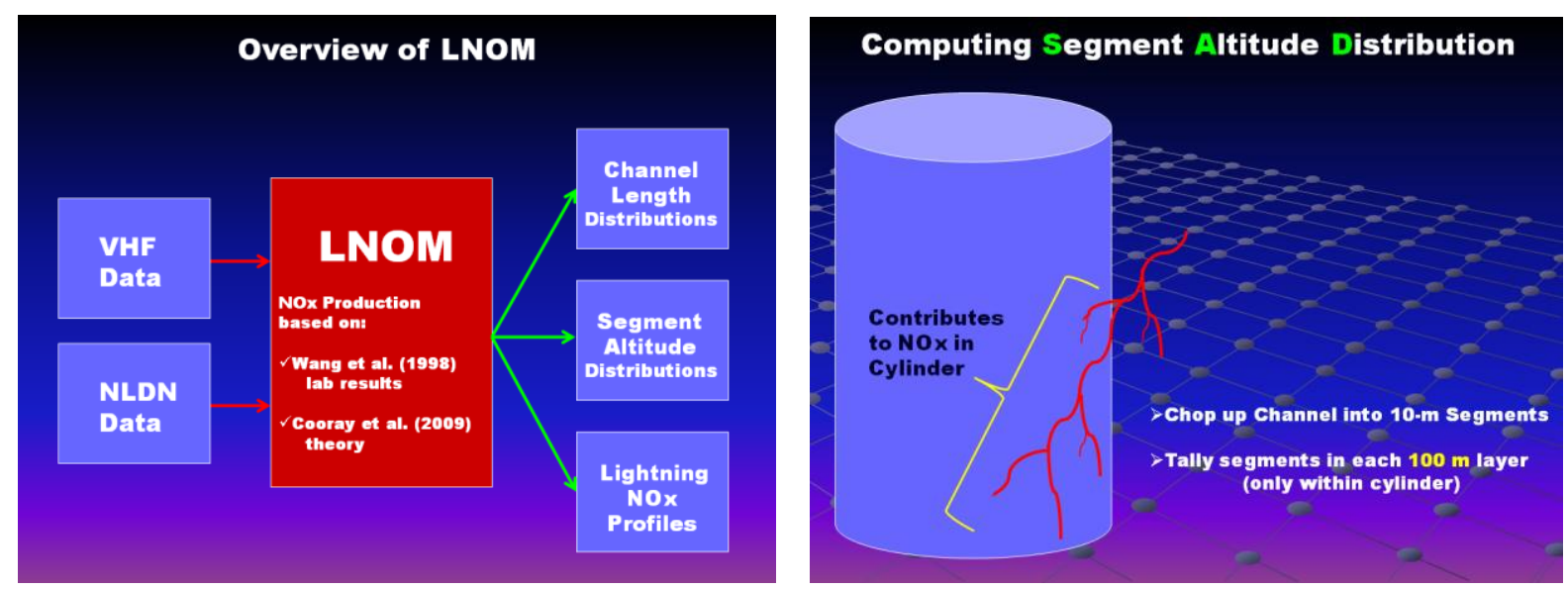

Figure 1. Functionality of the LNOM showing (left) inputs \& outputs, and (right) the analysis cylinder and details of channel segment altitude distribution computation.

\subsection{Recent Upgrades}

Upgrades to LNOM involve the addition of several important non-return stroke processes that produce NOx (see Cooray et al., 2009), but are often neglected by other investigators. Specifically, the LNOM upgrades include NOx contributions from: hot core stepped leader, hot core dart leaders, stepped leader corona sheath, K-changes, continuing currents, and M-components.

\subsection{Examples of LNOM Output}

Examples of the LNOM output for the August 2006 analysis period in Northern Alabama are provided in Figure 2. The LNOM also provides the component NOx profiles due to each separate production mechanism (i.e., return strokes, hot core stepped leaders, hot core dart leaders, stepped leader corona sheaths, K-changes, continuing currents, and M-components). The sum of these components gives the final result shown in the right-side plot of Figure 2. The average channel length of a flash (across all five Augusts) ranged from $38.9 \mathrm{~km}$ to $69.6 \mathrm{~km}$.

\section{LIGHTNING NOx STATISTICS}

The LNOM analysis of the five Augusts (2005-2009) has provided statistics of the amount of NOx produced by ground and cloud flashes, and by all flashes overall as shown in Table 1. 

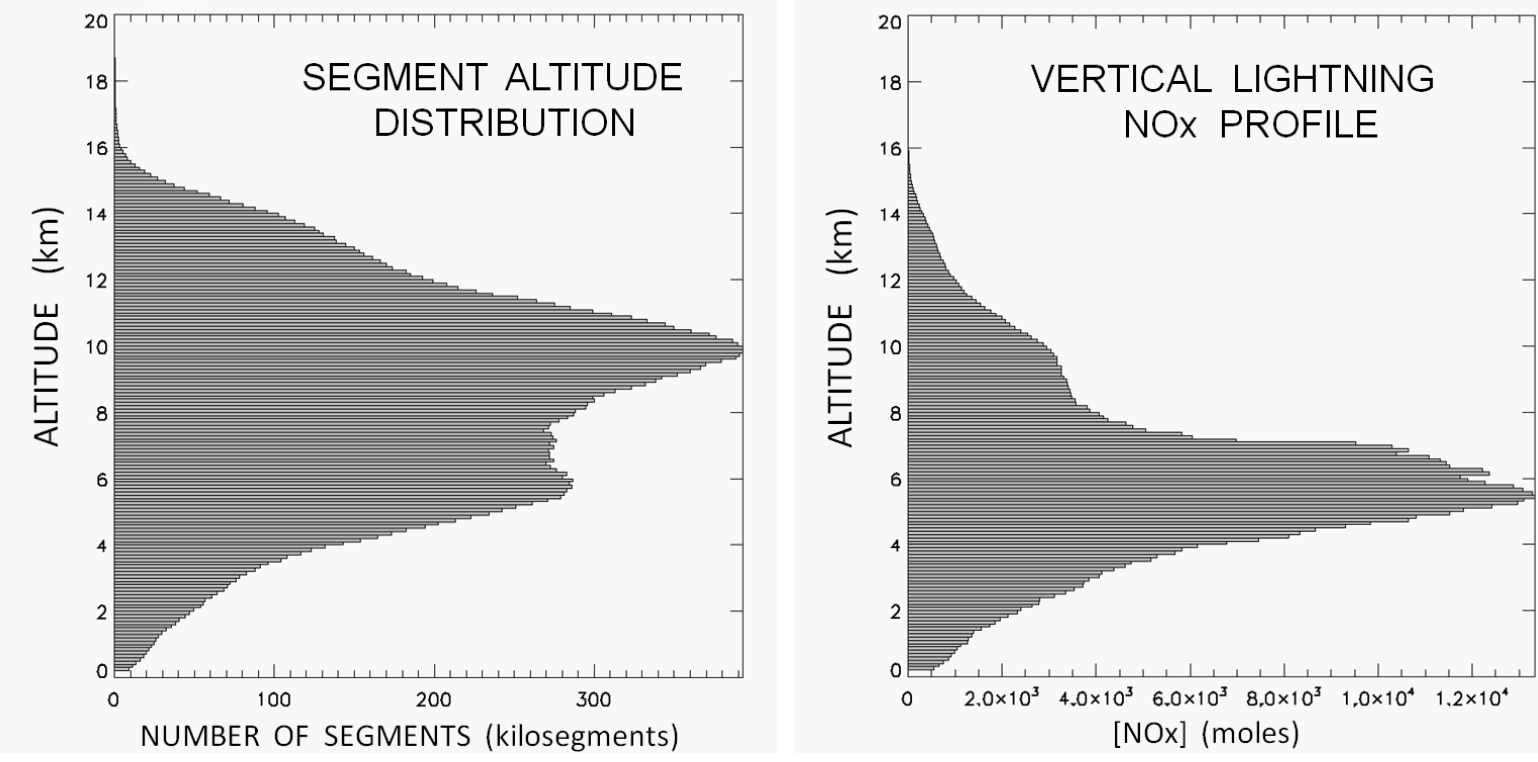

Figure 2. Example of two LNOM output products for the August 2006 analysis period.

\begin{tabular}{|c|c|c|c|c|c|c|}
\hline \multicolumn{2}{|c|}{ Table 1. LNOM summary statistics [NOx is in moles; NOx values are flash-count-weighted means]. } \\
\hline Period & $\begin{array}{c}\text { \# Ground } \\
\text { Flashes }\end{array}$ & $\begin{array}{c}\text { \# Cloud } \\
\text { Flashes }\end{array}$ & $\begin{array}{c}\text { Total \# of } \\
\text { Flashes }\end{array}$ & $\begin{array}{c}\text { NOx per } \\
\text { Ground Flash }\end{array}$ & $\begin{array}{c}\text { NOx per } \\
\text { Cloud Flash }\end{array}$ & $\begin{array}{c}\text { NOx per } \\
\text { Flash }\end{array}$ \\
\hline August 2005 & 1023 & 5306 & 6329 & 403.26 & 26.34 & 87.27 \\
\hline August 2006 & 1067 & 6986 & 8053 & 601.41 & 34.03 & 109.21 \\
\hline August 2007 & 1058 & 5766 & 6824 & 450.17 & 37.22 & 101.24 \\
\hline August 2008 & 1237 & 7563 & 8800 & 380.70 & 33.52 & 82.32 \\
\hline August 2009 & 447 & 2252 & 2699 & 756.08 & 54.97 & 171.09 \\
\hline Totals/Means & 4832 & 27,873 & 32,705 & $\mathbf{4 8 4 . 1 5}$ & $\mathbf{3 4 . 7 8}$ & 101.17 \\
\hline
\end{tabular}

\section{IMPACT ON AUGUST 2006 CMAQ RUN}

We summed the August 2005-2009 lightning NOx profiles and divided by the number of flashes (to obtain per flash NOx profiles). The August 2006 NLDN data was then used to find the number of ground flashes in each

MAX SFC 03 INCREASE DUE TO LNOX (ppb)

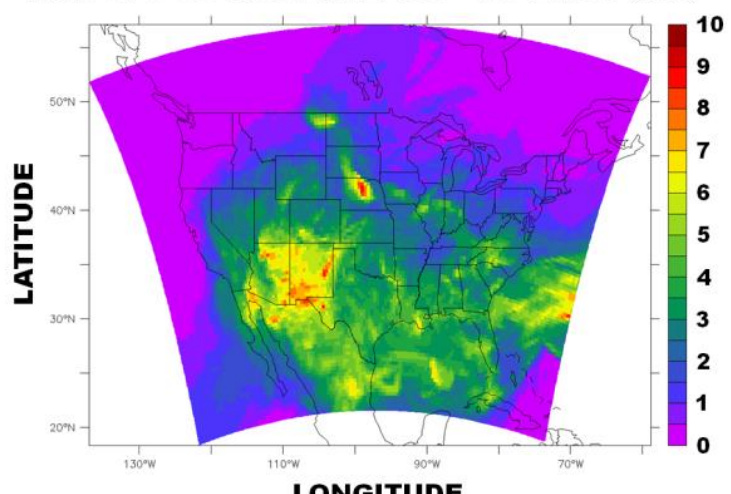

LONGITUDE
MAX 03 INCREASE DUE TO LNOX (ppb)

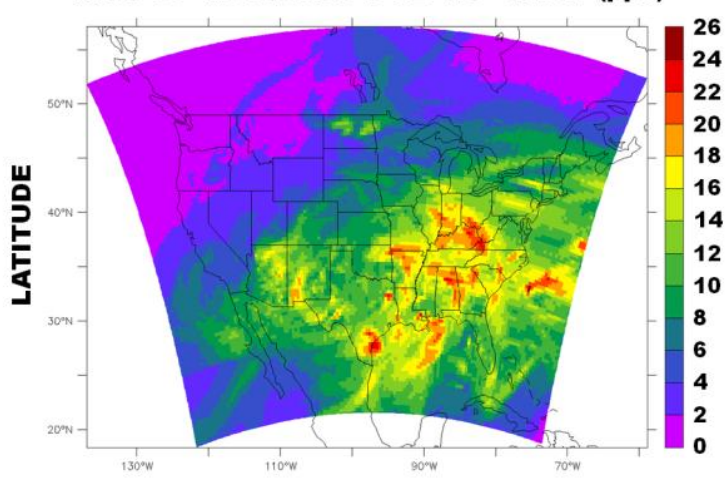

LONGITUDE

Figure 3. Impact of lightning NOx on ozone (left) at surface, and (right) at all levels. 
CMAQ grid cell; climatological Z-ratio data was used to estimate the associated number of cloud flashes. The ground and cloud flash counts were then multiplied by the respective per ground and per cloud flash lightning NOx profiles to estimate the lightning NOx profile within each CMAQ grid cell. The August 2006 CMAQ run was then completed. Figure 3 shows the impact of LNOM-derived lightning NOx on CMAQ ozone predictions.

\section{GLOBAL LIGHTNING NOx}

Using the statistics in Table 1, an estimate of global lightning NOx can be obtained. Christian et al. (2003) gives a global annual total of about $N=1,387,584,000$ flashes. Mackerras et al. (1998) estimates a global ground flash fraction range of between $0.154-0.215$, which has a midpoint $m=0.1845$. Using the weighted means from Table 1 give a total annual lightning NOx of: $m N(484.15)+(1-m) N(34.78)=1.633 \mathrm{E} 11$ moles $=2.287 \mathrm{Tg}(\mathrm{N})$.

\section{CONCLUSIONS}

It is feasible to combine LMA/NLDN data, laboratory measurements, and theory to make estimates of lightning NOx that are useful in air quality and global climate studies. The fixed 250 or 500 moles/flash values customarily assumed in the literature, with production by ground and cloud flashes set equal, is not optimal given the results in Table 1. The impact of lightning on air quality is significant (Figure 3). Finally, our $2.287 \mathrm{Tg}(\mathrm{N})$ estimate of global annual lightning NOx is regarded as a lower bound since most lightning occurs in the tropics where the tropopause is higher, leading to longer channel lengths and hence more lightning NOx production.

\section{ACKNOWLEDGMENTS}

The authors would like to thank Doreen Neil and Lawrence Friedl of NASA Headquarters for their support of this work through the NASA ROSES-NNH08ZDA001N-FEASIBILITY study, Ramesh Kakar [NASA Headquarters Program Manager for the Lightning Imaging Sensor (LIS) project], and the NASA Postdoc Program. We also thank Yun-Hee Park of the University of Alabama in Huntsville for supporting CMAQ runs.

\section{REFERENCES}

Christian, H. J., R. J. Blakeslee, D. J. Boccippio, W. L. Boeck, D. E. Buechler, K. T. Driscoll, S. J. Goodman, J. M. Hall, W. J. Koshak, D. M. Mach, M. F. Stewart, 2003: Global frequency and distribution of lightning as observed from space by the Optical Transient Detector, J. Geophys. Res., 108, No. D1, ACL 4-1- ACL 4-15.

Cooray, V., M. Rahman, V. Rakov, 2009: On the NOx production by laboratory electrical discharges and lightning, J. of Atmo. Solar-Terres. Phys., 71, 1877-1889.

Koshak, W. J., H. S. Peterson, E. W. McCaul, A. Biazar, 2010: Estimates of the lightning $\mathrm{NO}_{\mathrm{x}}$ profile in the vicinity of the North Alabama Lightning Mapping Array, International Conference on Lightning Detection, Orlando, FL.

Labrador, L. J., R. von Kuhlmann, M. G. Lawrence, The effects of lightning-produced NOx and its vertical distribution on atmospheric chemistry: sensitivity simulations with MATCH-MPIC, Atmos. Chem. Phys. Discuss., 4, 6239-6281, 2004.

Mackerras, D., M. Darveniza, R. E. Orville, E. R. Williams, and S. J. Goodman, 1998: Global lightning: Total, cloud and ground flash estimates, J. Geophys. Res., 103(D16), 19,791-19,809, doi:10.1029/98JD01461.

Schumann, U. and H. Huntrieser, 2007: The global lightning-induced nitrogen oxides source. Atmos. Chem. Phys., 7, 3823-3907.

Wang, Y., A. W. DeSilva, and G. C. Goldenbaum, 1998: Nitric oxide production by simulated lightning: dependence on current, energy, and pressure, J. Geophys. Res., 103, 19149-19159. 
W. Koshak ${ }^{1}$, H. Peterson ${ }^{2}$, M. Khan ${ }^{3}$, A. Biazar ${ }^{4}$, and L. Wang ${ }^{4}$

${ }^{1}$ Earth Science Office, Mail Stop VP61, NASA Marshall Space Flight Center, AL 35812.

${ }^{2}$ NASA Postdoctoral Program, National Space Science \& Technology Center, Huntsville, AL, 35805.

${ }^{3}$ Universities Space Research Association, National Space Science \& Technology Center, Huntsville, AL, 35805.

${ }^{4}$ University of Alabama in Huntsville, National Space Science \& Technology Center, Huntsville, AL, 35805.

\section{INTRODUCTION}

There has been considerable variability in the estimates of lightning NOx production per flash; see for example the summary table in Labrador et al. (2005), the review paper by Schumann and Huntrieser (2007), and the studies by DeCaria et al. (2000, 2005), Beirle et al. (2004, 2010), Langford et al. (2004), Rahman et al. (2007), Huntrieser et al. (2008), Jourdain et al. (2010), Ott et al. (2010), and Peterson and Beasley (2011). The variability in these estimates is linked to the differences in the estimation methods employed, and the natural variability of lightning.

The NASA Marshall Space Flight Center introduced the Lightning Nitrogen Oxides Model (LNOM; Koshak et al., 2009, 2010) to combine routine, state-of-the-art measurements of lightning with laboratory empirical results of lightning NOx production derived from Wang et al. (1998). The LNOM has recently been updated to include several non-return stroke lightning NOx production mechanisms described in Cooray et al. (2009): hot core stepped and dart leaders, stepped leader corona sheath, K-changes, continuing currents, and M-components. The impact of including LNOMestimates of lightning NOx for an August 2006 run of CMAQ is discussed. The input data into the LNOM includes VHF lightning source data [such as from the North Alabama Lightning Mapping Array (NALMA)], and ground flash location, peak current, and stroke multiplicity data from the National Lightning Detection Network (NLDN). Figure 1 summarizes LNOM data processing.
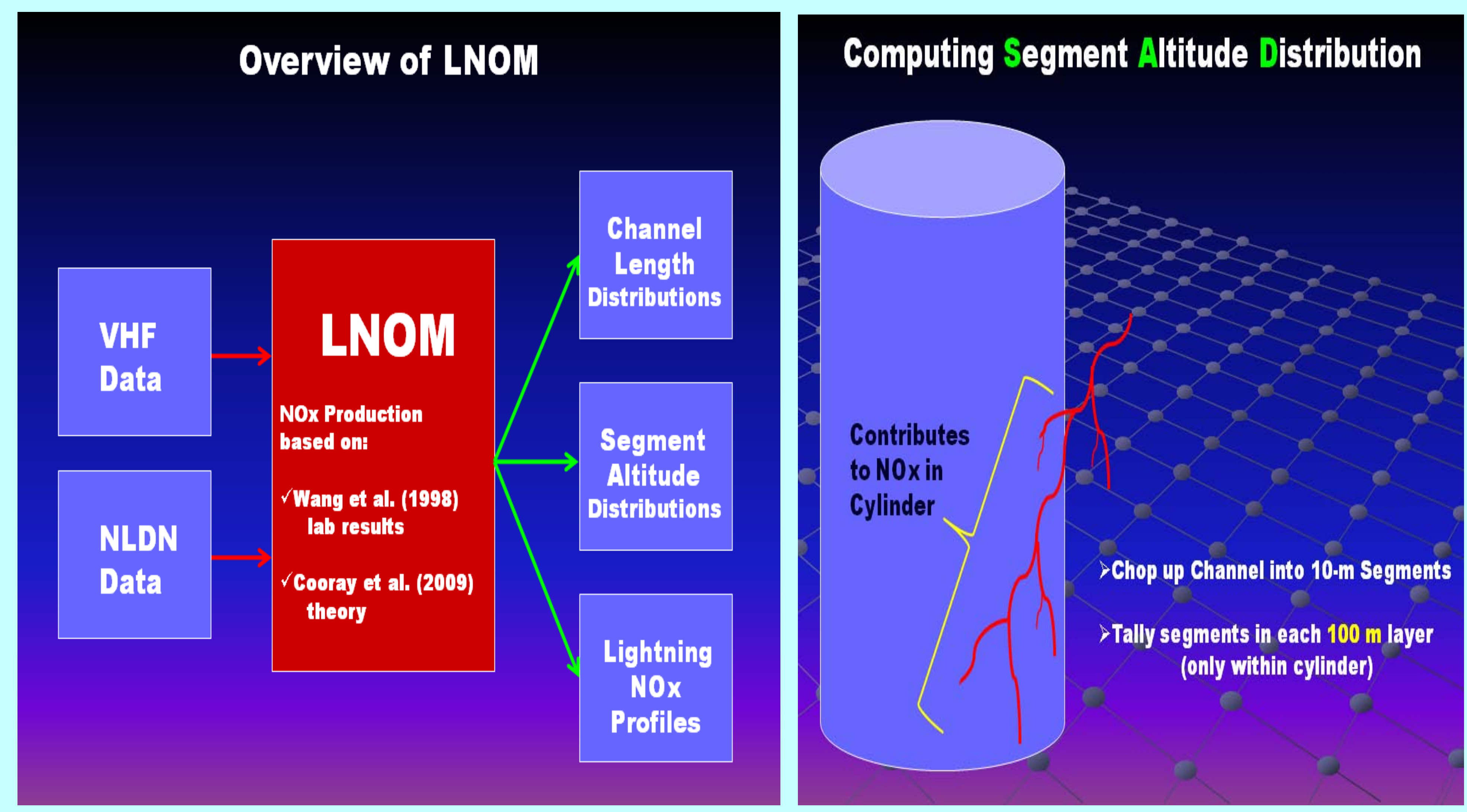

Figure 1. Functionality of the LNOM showing inputs, outputs, and details on channel segment altitude distribution computation.

\section{EXAMPLES OF LNOM OUTPUT FOR AUGUST 2006}

Figure 2 below provides examples of the LNOM output. LNOM output was also obtained for Aug 2005, Aug 2007, Aug 2008, and August 2009.
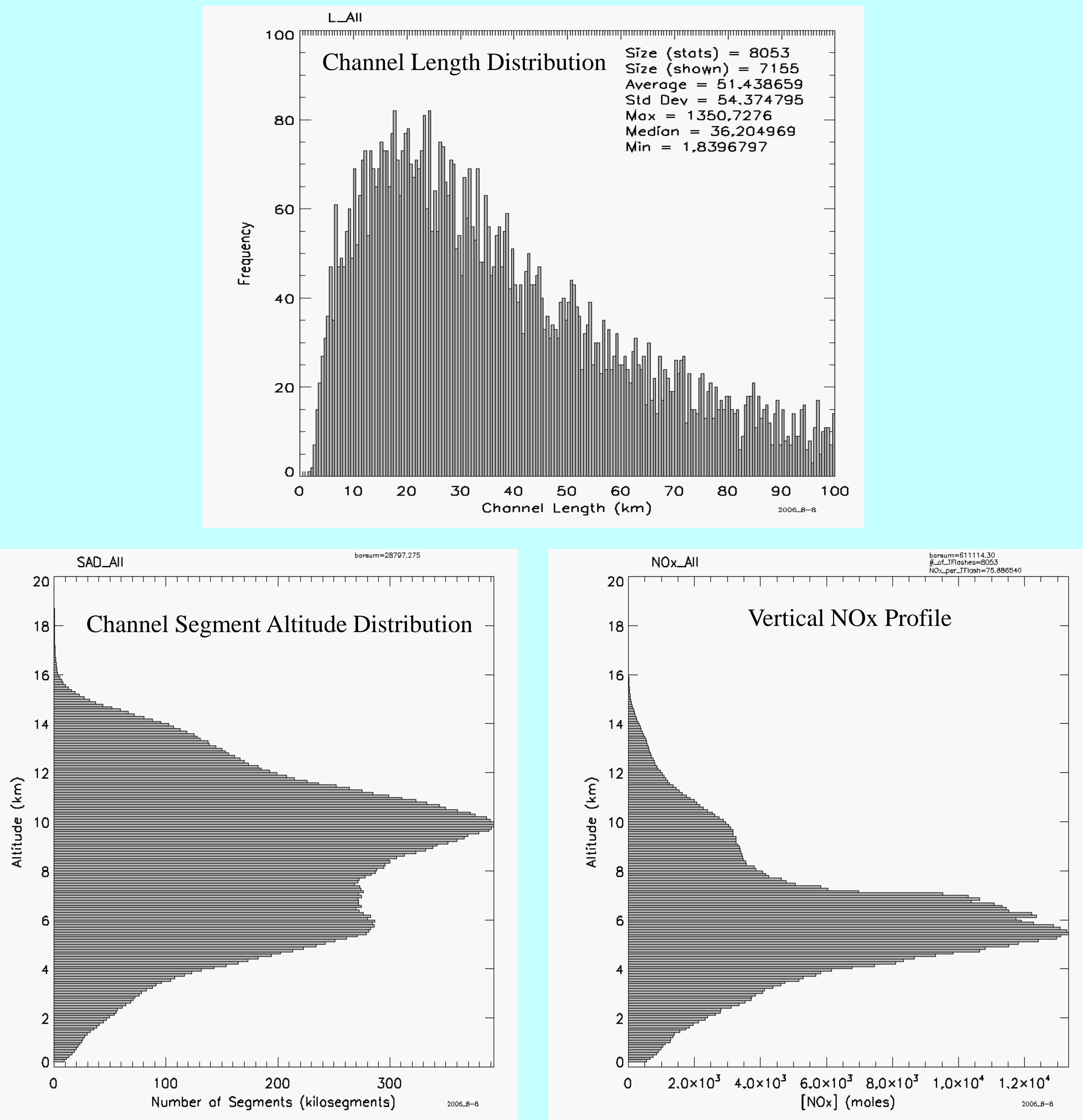

Figure 2. LNOM output: (top) channel length distribution, (lower left) channel segment altitude distribution, and (lower right) vertical NOx profile.

\section{LIGHTNING NOx \& CHANNEL LENGTH STATISTICS}

\begin{tabular}{|c|c|c|c|c|c|c|}
\hline \multicolumn{7}{|c|}{ Table 1 . Summary of lightring NOx production from LNOM analyses. } \\
\hline Period & $\begin{array}{l}\text { \#Ground } \\
\text { Flashes }\end{array}$ & \# Cloud Flashes & $\begin{array}{l}\text { Total \# of } \\
\text { Flashes }\end{array}$ & $\begin{array}{c}\text { Nox per } \\
\text { Ground Flash }\end{array}$ & $\begin{array}{l}\text { Nox per Cloud } \\
\text { Flash }\end{array}$ & N0x per Flash \\
\hline August 2005 & 1023 & 5306 & 6329 & 403.26 & 26.34 & 87.27 \\
\hline Augut 2006 & 1067 & 6986 & 8053 & 601.41 & 34.03 & 109.21 \\
\hline August 2007 & 1058 & 5766 & 6824 & 450.17 & 37.22 & 101.24 \\
\hline August 2008 & 1237 & 7563 & 8800 & 380.70 & 3352 & 82.32 \\
\hline August 2009 & 447 & 2252 & 2699 & 756.08 & 54.97 & 171.09 \\
\hline $\begin{array}{l}\text { TotalFlashes } \\
\text { Weighted Mean } \\
\text { Nox }\end{array}$ & 4832 & 27,873 & 32,705 & 484.15 & 34.78 & 101.17 \\
\hline
\end{tabular}

\section{APPLICATION TO CMAQ}

We summed the Aug 2005-2009 lightning NOx profiles and divided by the number of flashes (to obtain per flash NOx profiles; we also obtained the separate per ground flash and per cloud flash lightning NOx profiles). The August 2006 NLDN data was then used to find the \# ground flashes in each Community Multiscale Air Quality (CMAQ) grid cell; climatological Z-ratio data was used to estimate the associated \# of cloud flashes. The flash counts were then multiplied by the per flash lightning NOx profiles to estimate the lightning NOx profile input into each CMAQ grid cell. The Aug 2006 CMAQ run was then completed. Figure 3 shows the impact of LNOM-derived lightning NOx on CMAQ ozone predictions.
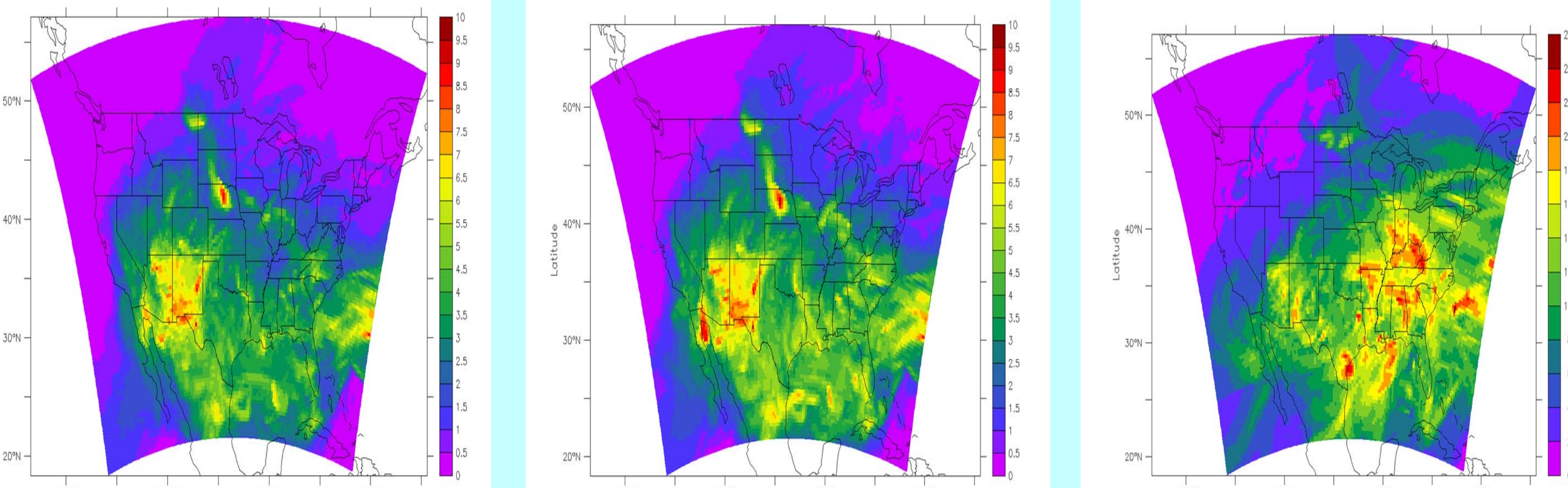

\section{REFERENCES}

Beirle, $\mathrm{S}, \mathrm{H}$

Beirle, S., U. Platt, M. Wenig, and T. Wagner, 2004: NOx production by lightning estimated with GOME, Adv. Space Res., 34, 793797.

Cooray, V., M. Rahman, V. Rakov, 2009: On the NOx production by laboratory electrical discharges and lightning, J. of Atmo. SolarTerres. Phys., 71, 1877-1889.

DeCaria, A. J., K. E. Pickering, G. L. Stenchikov, and L. E. Ott, 2005: Lightning-generated NOx and its impact on tropospheric ozone production: A three-dimensional modeling study of a Stratosphere-Troposphere Experiment: Radiation, Aerosols, and Ozone (STERAO-A) thunderstorm, J. Geophys. Res., 110, doi:10.1029/2004JD005556.

DeCaria, A. J., K .E. Pickering, G. L. Stenchikov, J. R. Scala, J. L. Stith, J. E. Dye, B. A. Ridley, and P. Laroche, 2000: A cloud-scale model study of lightning-generated NOx in an individual thunderstorm during STERAO-A, J. Geophys. Res., 105, 11601-11616.

Huntrieser, H., U. Schumann, H. Schlager, H. Holler, A. Giez, H.-D. Betz, D. Brunner, C. Forster, O. Pinto Jr., and R. Calheiros, 2008 : Lightning activity in Brazilian thunderstorms during TROCCINOX: implications for NOx production, Atmos. Chem. Phys, 8, 921-953. Jourdain, L., S. S. Kulawik, H. M. Worden, K. E. Pickering, J. Worden, and A. M. Thompson, 2010: Lightning NOx emissions over the USA constrained by TES ozone observations and the GEOS-CHEM model, Atmos. Chem. Phys., 10, 107-119.

Koshak, W. J., H. S. Peterson, E. W. McCaul, A. Biazar, 2010: Estimates of the lightning $\mathrm{NO}_{x}$ profile in the vicinity of the North Alabama Lightning Mapping Array, Proceedings of the International Lightning Detection Conference, Orlando, FL.

Koshak, W. J., M. N. Khan, A. P. Biazar, M. Newchurch, R. T. McNider, 2009:A NASA model for improving the lightning NOx emission inventory for CMAQ, Proceedings of the Joint Session: 4 Conference on the Meteorological Applications of Lightning Data and the $11^{\text {th }}$ Conference on Atmospheric Chemistry; $89^{\text {th }}$ Annual AMS Conference, Phoenix, AZ.

Labrador L. J., R. von Kuhlmann, M. G. Lawrence, 2005: The effects of lightning-produced NOx and its vertical distribution on atmospheric chemistry: sensitivity simulations with MATCH-MPIC, Atmos. Chem. Phys., 5, 1815-1834.

Langford, A. O., R. W. Portmann, J .S. Daniel, H. L. Miller, and S. Solomon, 2004: Spectroscopic measurements of NO2 in a Colorado thunderstorm: Determination of the mean production by cloud-to-ground lightning flashes, J. Geophys. Res, 109 doi:10.1029/2003JD004158.

Ott, L. E., K. E. Pickering, G. L. Stenchikov, D. J. Allen, A. J. DeCaria, B. Ridley, R.-F. Lin, S. Lang, and W.-K. Tao, 2010: Productio a lighting NOx and ins vetical distibution cal J Al Geophys. Res., 115, doi:10.1029/2009JD011880.

Peterson, H. S. and W. H. Beasley, 2011: Possible catalytic effects of ice particles on the production of NOx by lightning discharges, Atmos. Chem. Phys. Discuss., 11, 12649-12670, doi:10.5194/acpd-11-12649-2011.

Rahman, M., V. Cooray, V. A. Rakov, M. A. Uman, P. Liyanage, B. A. DeCarlo, J. Jerauld, and R. C. Or NOx produced by rocket-triggered lightning, Geophys. Res. Lett., 34, doi:10.1029/2006GL027956.

Schumann, U. and H. Huntrieser, 2007: The global lightning-induced nitrogen oxides source. Atmos. Chem. Phys., 7, 3823-3907.

Wang, Y., A. W. DeSilva, and G. C. Goldenbaum, 1998: Nitric oxide production by simulated lightning: dependence on current, energy, and pressure, J. Geophys. Res., 103, 19149-19159. 